\title{
The impact of formative assessment on self-regulating learning in university classrooms*
}

\author{
Fisseha Mikre Weldmeskel and Dreyer Johann Michael ${ }^{* *}$
}

doi: http://dx.doi.org/10.18543/tjhe-4(1)-2016pp99-118

\begin{abstract}
This study describes the extent of which the use of quality formative assessment on lessons of a course involves the students as self-regulated learners. There is an increased interest among educational researchers to observe improvement of student self-regulation on learning. The predominant use of summative assessment remains a challenge to helping students develop self-regulation skills in learning and assessment. Quality formative assessment includes formative feedback, self-assessment and peer assessment. The study followed a partially mixed sequential research design and applied a quasi-experimental intervention that lasted for six weeks where six educators applied quality formative assessment on lessons of a general psychology course for intervention group students $(\mathrm{N}=191)$. The quantitative data were collected by self-regulated learning questionnaire before and after the use of quality formative assessment on lessons. The qualitative data were collected by focus group discussions with the students. The students' perceptions on self-regulating learning were compared between the intervention $(\mathrm{N}=191)$ and the comparison $(\mathrm{N}=187)$ group of students. The quantitative analysis used t-test and biserial correlation and proved the presence of statistically significant difference between the two groups in perceiving the selfregulation of learning. Moreover, effect size estimate (Cohen's d) was used to provide a strong validation on the variation between the two groups for the measure of selfregulating learning. Recommendations were made to promote the use of quality
\end{abstract}

* The authors of this article want to extend their acknowledgment to Jimma University (Ethiopia) for the financial support it provided during the data collection. The University of South Africa (UNISA) deserves acknowledgment for facilitating a doctoral study admission and assigning the study supervisor for the main author. The authors would also like to thank the course teachers and students who actively participated in supplying the necessary data for the study.

* Dr. Fisseha Mikre Weldmeskel (fisseha.mikre@ju.edu.et) is associate professor of educational psychology at Jimma University (Ethiopia). His fields of specialization are curriculum \& instruction design, educational psychology, assessment and didactics. He has research interests in the areas of quality education, instruction design and assessment.

Professor Dreyer Johann Michael (Dreyejm1@unisa.ac.za) is professor of education at the University of South Africa (UNISA). His fields of specialization are didactics, practical teaching and assessment. He has research interests in the areas of practical teaching, environmental education and mentoring. 
formative assessment aiming at the improvement of student self-regulation on learning and assessment in university classes.

Keywords: Self-regulated learning; quality formative assessment; feedback; self-assessment; peer assessment; constructivist learning.

\section{Background of the study}

\section{I.1. Introduction}

This study examined the contribution of a quality formative assessment used on lessons of a course in involving the students as self-regulated learners in a "General Psychology" course at three west Ethiopian universities. Quality formative assessment denotes the delivery of formative feedback by educators, peer-assessment and self-assessment, which contribute to the improvement and the self-regulation on learning. Self-regulation of learning refers to the students' perceptions on self-regulating learning before and after an instructional intervention in which quality formative assessment was used on lessons of the course.

At present, Ethiopia considers education and training as an instrument of development and poverty alleviation. To realise this, the country set educational objectives which reflect the needs of the society. ${ }^{1}$ In relation to university education, one of the specific objectives incorporated in the policy states: "satisfy the country's need for skilled human power by providing training in the various skills and at different levels." In line with this, the country is rapidly expanding higher education, and student enrollment is also increasing. Moreover, there is a national concern and dedication to improve the quality and relevance of university education. The need for competence based education and the active role of the student are also key issues emphasised on the policy. However, assessment practices on course delivery in university classes often lack the student active involvement in self-regulating learning. Students at universities have not been fully engaged in assessment practices, which can enhance selfregulated learning skills. ${ }^{3}$ On the other hand, the contributions of formative feedback, peer assessment, and self-assessment to the country's university

\footnotetext{
${ }^{1}$ Ministry of Education (MOE), Education and Training Policy 1994 (Addis Ababa: MOE, 1994), 7-8.

${ }^{2}$ MOE, Education and Training Policy 1994, 9.

${ }^{3}$ Higher Education Relevance and Quality Agency (HERQA), "Jimma University institutional quality audit report 2008" (Addis Ababa: HERQA, 2008).
} 
education had not been well studied and documented. This study integrated quality formative assessment on the lessons of a course and found out the ways by which the student perception on self-regulation learning was enhanced.

\section{I.2. Conceptual model}

Conceptually, the constructivist learning paradigm was fundamental to inform this study, since the study examined the contribution of quality formative assessment to the improvement of self-regulated learning. Active student involvement and competence based learning are the major assumptions of constructivist learning. Students make sense of new knowledge by mapping it to their existing knowledge and they see instruction not only as the transmission of knowledge but also as intervention in an ongoing knowledge construction process. Moreover, there is an opportunity for the students to actively involve as self-and peer-assessors of their learning. The provision of effective feedback also contributes to self-regulate learning. As a result, educators consider formative assessment as an essential curriculum component that contributes to student self-regulation in learning. Hence, the following statement explains the logic for the conceptual alignment of this study with constructivist learning paradigm. A quality formative assessment that is integrated with instruction, involving the students as self-assessors, peer assessors, when accompanied with feedback improves student self-regulation on learning. Hence, this study raises an important research question that states, "To what extent can the use of quality formative assessment involve students with self-regulating learning as perceived and reported by themselves?

\section{Literature review and empirical evidence}

\section{II.1. Literature review}

Self-regulated learning can be taken as one outcome of using quality formative assessment in instruction. Over the last twenty years, the ways researchers conceptualise learning and assessing at the higher education context have been changing. ${ }^{4}$ Researchers tend to propose different approaches

${ }^{4}$ David J. Nicol and Debra M. Dick, "Formative assessment and self-regulated learning: a model and seven principles of good feedback practice," Studies in Higher Education 31, no. 2 (2006): 201. 
to learning and assessing, which can help in the improvement of student learning and self-regulation. One proposed approach that forms the basis for "student-centered learning" is self-regulation on learning. The need to expand the understanding on the role of students' in learning, as well as the practicable tactics of scaffolding self-regulated learning skills and assessment is well recognised. ${ }^{5}$ Although self-regulation has received little attention in the literature of formative assessment, researchers perceive self-regulation as a set of metacognitive, motivational and behavioural tactics which benefit the student to control and manage learning outcomes actively. ${ }^{6}$

Conceptually, self-regulated learning is a method by which a student actively participates in setting learning objectives and then attempt to monitor, regulate and control his/her cognition, motivation, and behaviour to achieve the objectives. ${ }^{7}$ Self-regulated learning is a self-directed activity by which a student transforms his/her mental abilities into academic skills and shows the initiative in the learning activity. ${ }^{8}$ Formative assessment plays a key role to increase self-awareness and self-regulation skills. For example, formative assessment guides the student's judgment about what is important to learn, and influence the perceptions on competence. ${ }^{9}$ Self-regulation involves interplay between commitment, control, and confidence. It addresses the way students monitor, direct, and regulate actions toward the learning objectives. It implies autonomy, selfcontrol, self-direction, and self-discipline. Such regulation involves "selfgenerated thoughts, feelings, and actions that are planned and cyclically adapted to the attainment of personal goals" and can lead to seeking, accepting, and accommodating feedback information..$^{10}$ Self-regulated

${ }^{5}$ Heidi L. Andrade, "Students as the definitive source of formative assessment: Academic self-assessment and the self-regulation of learning," in NERA Conference Proceedings 2010, Paper 25, ed. Northeastern Educational Research Association (NERA) (Rocky Hill: University of Connectut, 2010), accessed January, 2013. http://digitalcommons. uconn.edu/nera_2010/25/.

${ }^{6}$ Paul R. Pintrich, "The role of goal orientation in self-regulated learning," in Handbook of self-regulation, ed. Boekaerts M., Pintrich, PR and Zeidner, M. (San Diego, CA: Academic, 2000), 454.

7 Pintrich, "The role of goal orientation in self-regulated learning," 456.

${ }^{8}$ Barry J. Zimmerman, "Becoming a self-regulated student: An overview," Theory into Practice 41, no. 2 (2002): 65.

9 Lorrie Shepard. "Formative assessment: Caveat emptor: The Future of Assessment: Shaping Teaching and Learning" (paper presented at ETS Invitational conference, New York, October 10-11, 2005).

${ }^{10}$ John Hattie and Helen Temperley, "The power of feedback," Review of Educational Research 77, no. 1 (2007): 93-94. 
learning focuses on the management of learning by students. While students self-regulate learning, they take part to set achievement targets, stick to study schedules, and maintain the motivation and effort to achieve the targets. The self-regulation on learning is a key outcome in the implementation of quality formative assessment that contributes to learning improvement. Self-regulation is particularly salient in the higher education context because of the (often-implicit) expectations on student independence in learning. ${ }^{11}$ In self-regulation, learning can result from self-generated thoughts and behaviours that are systematically oriented towards the attainment of learning targets. ${ }^{12}$ The student's role here is significantly important. The proactive role of the student in generating and using feedback that enhances learning is also well-acknowledged. ${ }^{13}$ Educators at higher education can empower students as self-regulated learners by the continuous use of quality formative assessment and feedback. Educators also tend to attribute many of the individual differences in learning to the level of students' self-regulation skills. Selfregulated learning requires different skills. These are:

...(a)setting specific proximal goals for oneself, (b) adopting powerful strategies for attaining the goals, (c) monitoring one's performance selectively for signs of progress, (d) restructuring one's physical and social context to make it compatible with one's goals, (e) managing one's time use efficiently, $(f)$ self-evaluating one's methods, $(g)$ attributing causation to results, and $(h)$ adapting future methods.$^{14}$

Thus, it is proposed that the use of quality formative assessment "helps students to develop the mentioned self-regulated learning skills." ${ }^{15}$ In essence, then, self-regulated learning and effective feedback lead to improved learning gains. ${ }^{16}$ Students who self-regulate their learning are more effective in learning their subjects. ${ }^{17}$ These students show persistence, resourcefulness, confidence and high achievement. When students set superior goals proactively, monitor learning intentionally, use strategies effectively, and

${ }^{11}$ Keithia Wilson and Alf Lizzo, "A just in time intervention to support the academic efficacy of at risk first year students" (FYE Pacific Rim Conference: Griffith University, 2008), accessed June, 2011, https://www.griffith.edu.au/_data/assets/pdf_file/0005/224762/.

${ }^{12}$ Charity H. Johansson and Peter Felton, Transforming Students: Fulfilling the Promise of Higher Education (John Hopkins Press, 2014), 12.

${ }_{13}$ Nicol and Dick, "Formative assessment and self-regulated learning," 199.

${ }^{14}$ Zimmerman, "Becoming a self-regulated student," 66.

15 Zimmerman, "Becoming a self-regulated students," 66.

${ }^{16}$ Nicol and Dick, "Formative assessment and self-regulated learning," 210.

17 Zimmerman, "Becoming a self-regulated students," 66. 
respond to feedback adaptively, they not only attain mastery but also sustain their motivation and efforts in learning. ${ }^{18}$

Quality formative assessment involving formative feedback, self and peer assessment enhances student self-regulation on learning. However, existing research demonstrates that self- and peer assessment are not common assessment practices. ${ }^{19}$ The perception of students on formative assessment and self-regulation of learning influences its use and effectiveness. The research literature recognises perception as a major challenge to the use of formative assessment that enhances self-regulated learning in the classroom context. The perception of the student is important, mainly because in the implementation of quality formative assessment, the student assumes an increased responsibility to regulate and self-reflect on his/her own learning and assessment.

\section{II.2. Empirical evidence}

The literature with respect to empirical evidence clarified the contribution of formative assessment to the self-regulation of learning. In fact, the effect of innovative assessment practices on students' learning experience at higher education is a neglected research topic. ${ }^{20}$ From the empirical literature, it was learned that students value improvement-oriented assessment methods. There are also evidences which support the positive influence of formative assessment to improve self-regulation and academic performance. Moreover, some of the research evidences show significant differences with respect to average effect sizes in the students' self-regulation perception scores between an intervention and comparison groups, when formative assessment was used on lessons. The empirical evidences confirm the advantage of immediate and corrective feedback provision to contribute for student selfregulation on learning. Furthermore, research findings substantiate the significance of self-assessment to bring about critical reflection and the development of autonomous and self-regulated learning skills. In some of the studies reviewed, students perceived peer assessment positively, despite complaints on its unfairness and lack of accuracy. Hence, the question in this

18 Barry J. Zimmerman, "From Cognitive Modeling to Self-Regulation: A Social Cognitive Career Path," Educational Psychologist 48, no. 3 (2013): 137.

19 Andrade, "Students as the definitive source of formative assessment," 5.

${ }^{20}$ Sheena Bevitt, "Assessment innovation student experience: A new assessment challenge and call for a multi- perspective approach to assessment research," Assessment and Evaluation in Higher Education 40, no. 1 (2015): 103. 
study is, how do students differ in their perceptions towards self-regulating learning when educators use quality formative assessment on lessons of a university course.

\section{Research Design and Methods}

\section{III.1. Research design}

This study situated itself within the pragmatic paradigm of studying the relationship of research variables. This is because the research question set, call for objective data from self-regulated learning perception questionnaire as well as subjective data on the personal experiences of students obtained by focus group discussions. The pragmatic paradigm requires the mixing of quantitative and qualitative methodologies. The quantitative methodology is useful because the study followed empirical methods of data collection, analysis and interpretation of research variables with quantitative characteristics through quasi-experimental procedures, which lasted two weeks for the pilot study and four weeks for the main study. The qualitative methodology is also useful to look into the complexity of research participants' perceptions.

As mentioned earlier, the objective of this study was to examine the extent of which the use of quality formative assessment on lessons of a course involves the students as self-regulated learners. Therefore, it was necessary to collect data from the group, who experienced the effect of the use of quality formative assessment. To achieve the objective, the study followed a mixed method research design. Mixed method is a research design that integrates quantitative and qualitative data either concurrently or sequentially at one or more stages of the research process.$^{21}$ This design of research is advantageous because it uses the strengths of both methods, and their combined use provides an expanded understanding of the research variables. ${ }^{22}$ A mixed-methods approach is also useful since it compensates the weakness of one by the strength of the other. In the present study, to supplement the quantitative data, qualitative data was collected based on a

${ }^{21}$ John W. Creswell, Vicki L. Plano Clark, Michelle L. Gutmann, and William E. Hanson, "Advanced Mixed Methods Research Designs," in Handbook of mixed methods in social and behavioral research, ed. Abbas Tashakkori and Charles Teddlie (Thousand Oaks, CA: Sage, 2003), 235.

${ }_{22}$ John Creswell, Research design: A qualitative, quantitative and mixed-method approaches, $3^{\text {rd }}$ ed. (London: Sage Publication inc, 2009), 206. 
sequential explanatory strategy. Specifically, the study followed a mixed method research design of the type partially mixed sequential dominant status in which a main quantitative study was sequentially followed by a qualitative study. ${ }^{23}$ This type of mixed method design is useful when researchers intend to conduct the study by giving emphasis to the quantitative methodology. Partially-mixed sequential design is used when there is an intention to examine a large sample first to test the relationship of research variables and then to investigate in more depth with a few cases in the qualitative phase. ${ }^{24}$ In this approach, the collection and analysis of qualitative data usually follows and supplements the collection and analysis of quantitative data. ${ }^{25}$ In the present study, the researchers, first collected and analysed the quantitative data, collected and analysed the qualitative data, and then mixed the two in the interpretation and discussion phases of the study. ${ }^{26}$

\section{III.2. Sampling and data collection procedures}

In selecting the sample respondents for this study, the researchers used simple random sampling technique to identify students of intact classes for the quasi-experimental procedure. For instance, the selection of three universities which took part in the study was made by the lottery-draw method. From each of the universities included in the study, two entire classes of students who were enrolled for "General Psychology" course in the academic year 2013/14 were randomly selected for inclusion in the intervention group. Two other classes taking a similar course to that of the intervention group were also identified as comparison groups to supply the quantitative data for the study. Therefore, the number of students who participated in the study was 464 including both the intervention and the comparison groups, of which only $378(81.46 \%)$ filled out the selfregulated learning perception questionnaire completely. The sample size $(n=378)$ is representative of the student population $(\mathrm{N}=6500)$ enrolled for "General Psychology" course at the six Universities. The collection of data for this study was carried out in two steps. The first step was the

${ }^{23}$ Nancy Leech and Anthony Onwuegbuzie, "An array of qualitative data analysis tools: A call for data analysis triangulation," School Psychology Quarterly 22, no. 4 (2007): 570.

${ }^{24}$ Creswell et al., "Advanced mixed methods research designs," 171.

${ }^{25}$ Creswell, Research design: A qualitative, quantitative and mixed-method approaches, 211.

${ }^{26}$ Creswell et al., "Advanced mixed methods research designs," 178. 
collection of baseline data before the quasi-experimental intervention. The baseline data included determining the students' perceptions on the practices of quality formative assessment and finding out whether this enhanced their self-regulation on learning. During the second step, data were collected by means of questionnaire re-administration, and focus group discussions.

\section{III.3. Data analysis}

The quantitative data outputs comprised both descriptive and inferential statistics. Descriptive statistics were used to present the participants' perception scores on the self-regulation of learning resulting from the use of quality formative assessment. The inferential statistics such as t-test, biserial correlation, and effect size estimate were used to determine the presence of statistically significant and valid variation between the students in the intervention and in the comparison groups on the measure of self-regulated learning perception. In fact, before this, analysis of the baseline data was done to establish the precondition for applying the quasi-experimental procedure in the form of instructions using quality formative assessment on lessons taught for the intervention group students.

On the other hand, qualitative data analysis is practicable for answering "why" and "how questions" in research. For example, "How do students perceive self-regulating learning in the instructional process of a university courses? Since, it is mostly concerned with the complex nature of human behaviour in a social context, qualitative data can be analysed in different ways. ${ }^{27}$ The specific method of qualitative data analysis followed in this study was the constant comparison method, for its relevance and simplicity when applied to several types of data such as Focus Group Discussions (FGDs). ${ }^{28}$ This method of qualitative data analysis is useful to identify the underlying themes emerging from the research data set. The researchers read through all the data before applying the constant comparison method. After that, the data were organised into smaller chunks. Afterwards, every chunk of data was given a label with a describing code. After all the data had been coded, the codes were grouped in terms of similarity and themes

${ }^{27}$ Keith Punch, Introduction to social research: Quantitative and qualitative approaches, $2^{\text {nd }}$ ed. (New Delhi: Sage, 2005), 5.

${ }^{28}$ Leech and Onwuegbuzie, "An array of qualitative data analysis tools: A call for data analysis triangulation," 586 . 
were distinguished based on each grouping. ${ }^{29}$ Finally, the themes were used for interpretation based on how they relate to the research question raised in the study.

\section{Results and Discussion}

\section{IV.1. Results}

The active role of students has implication for learning improvement. This can be made possible by stimulating self-regulated learning. Selfregulated learning involves the students' metacognitive, behavioural and motivational tactics to attend their learning progress actively. In this study, a thirteen (13) items questionnaire (see annex 1), with internal reliability coefficient of 0.92 to show the homogeneity of items in the scale was used to measure the students' perception in self-regulating learning on a general psychology course before and after the instructional intervention conducted with the intervention group. The assessment scale was from 1 (= always not true) to 4 (=always true). For the base-line data (i.e. before the lessons took place), the average overall (i.e. summed over all 13 items) score of perception on self-regulating learning was 32.73 with a standard deviation of 4.31 for the comparison group and 32.09 with a standard deviation of 3.89 for the intervention group respectively.

\section{Table 1}

Base-line data on the perception of self-regulating learning

\begin{tabular}{|l|c|c|}
\hline \multicolumn{1}{|c|}{ Group } & Mean score & SD \\
\hline Comparison & 32.73 & 4.31 \\
\hline Intervention & 32.09 & 3.89 \\
\hline
\end{tabular}

These mean ratings are half-way on the scale measure, between 26 (i.e. 13 items x 2, corresponding to all ticks being "mostly not true") and 39 (i.e. 13 items x 3, corresponding to all ticks being "mostly true"). Thus, it can be said, according to the perceptions of the students there was little or no

${ }^{29}$ Leech and Onwuegbuzie, "An array of qualitative data analysis tools: A call for data analysis triangulation," 591. 
enhancement to the self-regulation of learning on the lessons of the general psychology course before the use of quality formative assessment. The Levene's test (see table 2) for equality of variances on the perceptions of selfregulating learning showed no statistically significant difference between the two groups $(\mathrm{P}=0.65>0.05, \mathrm{df}=1 \& 376)$. This can be taken as a satisfactory pre-condition for the quasi-experimental procedure, where quality formative assessment was integrated with instruction and used on the lessons taught for the intervention group.

Table 2

Levene's test for equality of variances on the perceptions of self-regulating learning

\begin{tabular}{|c|c|c|c|c|c|c|c|}
\hline \multicolumn{1}{|c|}{ Variable } & Group & Mean & SD & df & $\begin{array}{c}\text { F- ratio } \\
\text { Table } \\
\text { value }\end{array}$ & $\begin{array}{c}\text { F-ratio } \\
\text { observed }\end{array}$ & $\begin{array}{c}\text { Level of } \\
\text { signifi- } \\
\text { cance }\end{array}$ \\
\hline $\begin{array}{l}\text { Self-regulated } \\
\text { learning, } \\
\text { perception }\end{array}$ & Comparison & 32.73 & 4.31 & $\begin{array}{c}1 \\
\&\end{array}$ & 3.84 & 0.65 & 0.05 \\
\cline { 2 - 7 } & Intervention & 32.09 & 3.89 & 376 & & \\
\hline
\end{tabular}

After the use of quality formative assessment on lessons, the thirteen items-questionnaires that elicited the students' perceptions on self-regulating learning was re-administered to both groups. As shown in table 3 and figure 1 , a change in the mean perception of self-regulating learning was reported for both groups. For instance, the mean perception on self-regulating learning for the comparison group students $(\mathrm{N}=187)$ was 34.14 with a standard deviation of 5.11 and the mean perception on self-regulating learning for the intervention group students $(\mathrm{N}=191)$ was 41.04 with a standard deviation of 3.94. According to this data, there was an increment in the mean perception scores equal to 6.90 .

\section{Table 3}

Mean perception scores increments

\begin{tabular}{|c|c|c|c|c|}
\hline Group & Pretest mean & Posttest mean & Pretest SD & Posttest SD \\
\hline Comparison & 32.73 & 34.14 & 4.31 & 5.11 \\
\hline Intervention & 32.09 & 41.04 & 3.89 & 3.94 \\
\hline
\end{tabular}




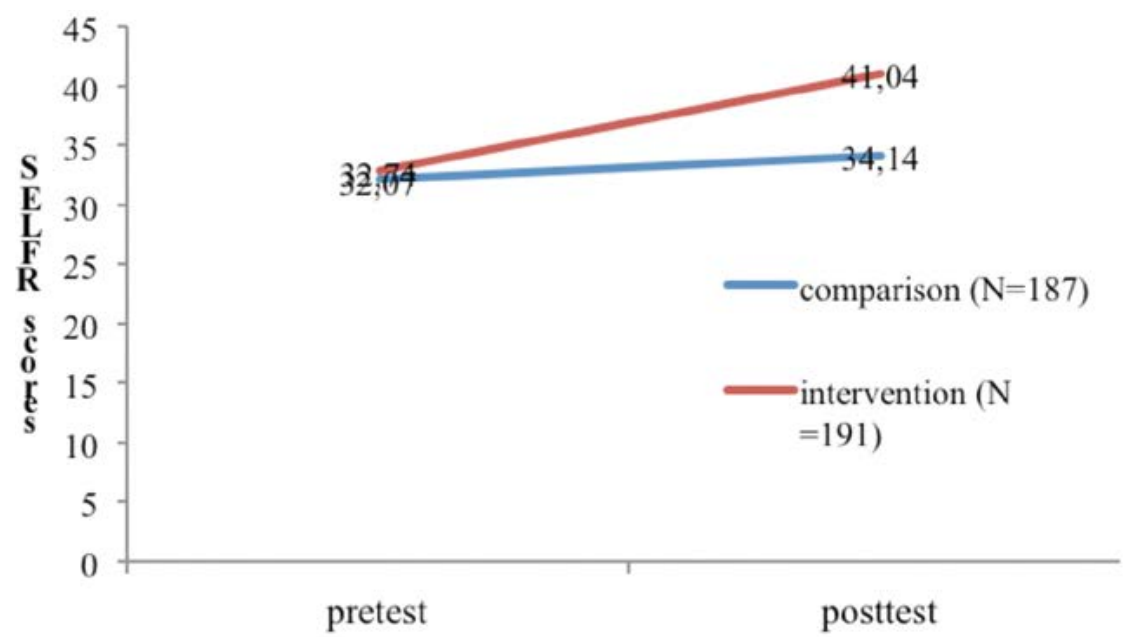

Figure 1

Comparisons of self-regulation mean scores

The independent samples mean difference test (t-test) that assumed unequal variances between the two groups - as the Levene test had shown revealed a statistically significant difference $(t=14.72, d f=376, \alpha .<0.00)$ between the intervention and the comparison group, where the intervention group perceived self-regulating learning as improved after the use of quality formative assessment (see table 4 below). The critical $t$-value (at $d f=376$ ) is 3.29 that means the observed t-value (14.72) is considerably higher than the critical value. The difference on the perceptions of self-regulated learning is attributed to the use of quality formative assessment on lessons of the course.

Table 4

Perception of self-regulating learning (post intervention)

\begin{tabular}{|c|c|c|c|c|c|c|c|c|}
\hline Group & $\begin{array}{c}\text { Mean } \\
\text { scores }\end{array}$ & SD & $\begin{array}{c}\text { Mean } \\
\text { differ. }\end{array}$ & $\begin{array}{c}\text { T-value } \\
\text { (Table } \\
\text { value } \\
=1.96)\end{array}$ & df & Assumption & $\begin{array}{c}\text { Sig. } \\
(p=. \\
05)\end{array}$ & Remark \\
\cline { 1 - 5 } Comp. & 34.14 & 5.11 & \multirow{2}{*}{6.9} & 14.72 & 376 & $\begin{array}{c}\text { Unequal } \\
\text { variances }\end{array}$ & 000 & $\begin{array}{c}\text { There is } \\
\text { statistically } \\
\text { significant } \\
\text { difference. }\end{array}$ \\
\hline Interv. & 41.04 & 3.94 & & & & & &
\end{tabular}


On the other hand, the biserial correlation coefficient was computed between the self-regulated learning perception score as a continuous variable and the students' placement in either the comparison or the intervention group as dichotomous variable. The t-test only shows variation between the two groups. It does not completely assure whether the use of formative assessment brings the students' involvement in self-regulating learning. Thus, the biserial correlation was used to check whether there was a relationship between placement in the intervention group where formative assessment was used and the involvement of the students in self-regulating learning. Therefore, the observed biserial correlation (rb) was found to be considerably higher than the critical correlation coefficient at the specified degrees of freedom $(\mathrm{rb}=0.61$ with degrees of freedom $=376$ ), where the expected correlation coefficient (the cut off value) at alpha $=0.05$ is 0.19 or less. This shows the presence of a statistically significant relationship between placements in the intervention group where quality formative assessment was used on lessons and the students' perceptions on self-regulating learning. Furthermore, effect size for the students' perception difference on self-regulating learning was estimated using the raw scores mean difference, and the standardised mean difference methods. The raw score mean difference between the two groups on perceiving the self-regulation of learning was 6.90 score points. The effect size estimate on standardised mean difference was 0.77 , which means, according to the convention about estimates of effect size from quasi-experimental intervention, that this is judged close to a higher effect. ${ }^{30}$

Similarly, focus group discussant students also confirmed the contributions of quality formative assessment to the quality of learning and to have positive effects on the self-regulation of learning as well as changing the students' attitudes to be more positive and active towards learning and assessment. The uses of self and peer assessment were advantageous because they were motivating to promote the active attention and involvement of the students in learning and assessing. According to the opinion of the focus group discussants, self-assessment facilitated for independent learning. They also reported peer assessment to stimulate student motivation and competition. In this study, therefore, the instructional intervention that integrated the use of quality formative assessment produced a positive effect on the students' perception of self-regulating learning. As the finding in this study revealed, the use of quality formative assessment on lessons significantly changed the students' perception on self-regulating learning. For instance, self-assessment

${ }^{30}$ Jacob Cohen, Statistical power analysis for the behavioural sciences (New York: Routledge Academic, 1988), 6. 
raises students' self-regulation skills and stimulates them to achieve better. ${ }^{31}$ In the present study, more than half of the students reported to perceive selfassessment as motivating and helpful for the self-regulation of learning. This result is similar to a study where students reported that they are motivated, able to self-regulate their learning, and learn in different ways as a result of self-assessment activities on lessons. ${ }^{32}$ The association among the active involvement of students in self-assessment, motivation, self-regulation of learning and marked improvement in achievement was also noted. ${ }^{33}$ Autonomous learning and reflective thinking are important learning goals in the context of higher education. ${ }^{34}$ Self-assessment produces responsible and autonomous students who can self-regulate learning. ${ }^{35}$ The students who took part in the FGDs also reported the usefulness of the self-assessment practice to help for independence, autonomy and acquisition of self-regulated learning skills. Peer assessment not only improves the quality of learning but also empowers students. The usefulness of peer assessment lies on the chance of greater involvement it gives to students to self-regulate learning. A student may gain insight into his/her own learning and performance when assessing other student's work. Peer assessment enables students to selfassess their own learning better $.^{36},{ }^{37}$ Students in this study also witnessed peer assessment as a useful activity to contribute for implicit motivation, competition and self-regulation on learning.

\section{IV.2. Discussion}

Self-regulation is central to "student-centred learning," and it is a significant feature of learning. It is predictive of improved academic outcomes

${ }^{31}$ Parvis Birjandi and Nasrin H. Tamjid, "The role of self-assessment in promoting Iranian EFL students' motivation," English Language Teaching 3, no. 3 (2010): 217.

${ }^{32}$ Kay Sambell and Liz McDowell, "The construction of the hidden curriculum: message $\mathrm{s}$ and meaning in the assessment of student learning," Assessment and Evaluation in Higher Education 23, no. 4 (1998): 398.

${ }^{33}$ Andrade, "Students as the definitive source of formative assessment: Academic selfassessment and the self-regulation of learning," 4.

${ }^{34}$ Sambell and McDowell, "The construction of the hidden curriculum: messages and meaning in the assessment of student learning," 399.

${ }_{35}$ Zimmerman, "Becoming a self-regulated students," 68.

${ }^{36}$ Ngar Lui and Careless David, "Peer feedback: The learning element of peer assessment," Teaching in Higher Education 11, no. 3 (2006): 281.

${ }^{37}$ Jing Yan Lu and Nancy Law, "Online peer assessments: effects of cognitive and affective feedback," Instructional Science 40, no. 2 (2012): 261. 
and motivation, enhanced involvement in the learning process and subsequent successful performance. ${ }^{38}$ Students can play a significant role in selfregulating learning and assessment. ${ }^{39}$ Self-regulation is conceptualised as a set of metacognition, behaviour and motivational tactics that the student applies to manage his/her learning outcomes actively. ${ }^{40}$ Self-regulation then refers to self-generated thoughts, feelings and behaviours that are directed towards achieving the intended learning objectives ${ }^{41}$ Students who have the skills to self-regulate learning focus on how they activate, alter and sustain specific learning activities. In a situation where such essential qualities of learning are absent, coaching students to develop self-regulated learning skills is especially relevant. ${ }^{42}$

The use of quality formative assessment on lessons can play a key role in the development of self-regulated learning skills. Student self-regulation has salience in the context of higher education because of the need for relative independence of the student. ${ }^{43}$ Research evidence shows the usefulness of selfregulated learning skills for enhancing student motivation and achievement. ${ }^{44}$ Thus, researchers suggest that educators at higher education should use formative assessment and feedback to enhance student self-regulation and independence in learning and assessing. A self-regulated student displays superior achievement gains and personal efficacy.$^{45}$ Students who self-regulate their learning are characterised by personal initiation, perseverance and adaptive skills..$^{46}$ They are also capable of monitoring, directing and regulating actions towards the learning objectives. ${ }^{47}$ It is also understood that the effective use of quality formative assessment paves the way for motivation and selfregulation to learning and assessment. In the present study, the students who

${ }^{38}$ Ian Clark, "Formative assessment: Policy, perspectives and practice," Florida Journal of Educational Administration and Policy 4, no. 2 (2011): 170.

39 Andrade, "Students as the definitive source of formative assessment: Academic selfassessment and the self-regulation of learning," 9.

${ }^{40}$ Pintrich, "The role of goal orientation in self-regulated learning," 454.

${ }^{41}$ Zimmerman, "Becoming a self-regulated students," 65.

${ }^{42}$ Zimmerman, "Becoming a self-regulated students," 70.

${ }^{43}$ Wilson and Lizzo, "A just in time intervention to support the academic efficacy of at risk first year students," 2 .

${ }^{44}$ Barry J. Zimmerman, "Developing Self-Fulfilling Cycles of Academic Regulation: An Analysis of Exemplary Instructional Models," in Self-Regulated Learning, ed. Schunk, DH \& Zimmerman, BJ (New York: Guilford, 1998),8.

${ }^{45}$ Zimmerman, "Becoming a self-regulated students," 66.

${ }^{46}$ Zimmerman, "Developing Self-Fulfilling Cycles of Academic Regulation: An Analysis of Exemplary Instructional Models," 14.

${ }^{47}$ Hattie and Temperley,"The power of feedback," 47. 
were taught by the use of quality formative assessment reported a better involvement in self-regulating their learning and also outperformed the comparison group by the post-test achievement score. Thus, effective use of quality formative assessment improves the involvement of students in learning and also achievement in tests. A similar study showed that students who selfregulate their learning are those who achieve significantly higher grades than those who achieved lower grades. ${ }^{48}$ In the present study, the students in the intervention group reported an improved involvement and experience in selfregulating learning. The greater and significant variation in the perception of self-regulation between the students might be attributable to the quality formative assessment that was used on lessons. Furthermore, in an attempt to self-regulate learning and assessment, students direct their thoughts and behaviours towards achieving the set learning goals. ${ }^{49}$ As a result of selfregulated learning, the students' motivation and effort to achieve high scores in tests increases. This was clearly seen in the present study. The students who were placed in the intervention group outperformed the students who were placed in the comparison group on the posttest achievement score.

\section{Conclusion and Recommendations}

The mean perception score on self-regulating learning for the intervention and comparison group students varied significantly. The result confirms that the students who were taught by the use of quality formative assessment on lessons report more involvement in self-regulating learning than those who were not taught by the use of quality formative assessment. Thus, the use of quality formative assessment contributes to the enhancement on the students' level of involvement and experience in self-regulating learning. As a result of this, inference can be made on the presence of a strong and statistically significant relationship between the students' placement in the intervention group where the teaching of the course integrated quality formative assessment and their perceptions in self-regulating learning with a magnitude of near to high effect size. As learned from the views of the students who took part in the focus group discussions, there was a positive perception for using quality formative assessment on lessons.

${ }^{48}$ Paul Pintrich and Elsabeth De Groot, "Motivational and self-regulated learning components of classroom academic performance," Journal of Educational Psychology 82, no. 1 (1990): 36.

49 Johansson and Felton, Transforming Students, 13. 
The students perceived formative assessment as encouraging with respect to making the learning and assessment process more involving and interactive. They also pointed out the promising effect and the usefulness of formative assessment to the students' motivation and active participation in learning. The focus group discussant students also revealed the benefits of each form of quality formative assessment to promote self-regulated learning skills. For instance, formative feedback encouraged active learning to occur, self-assessment facilitated relative independence and autonomy for the students and peer assessment enhanced the students' motivation, responsibility and competition on learning. Nevertheless, despite their optimistic perceptions on the advantages of quality formative assessment, the students expressed their concerns because of the amount of time consumed by the assessment activities against the coverage of course content. Even so, in general terms, they favour the use of quality formative assessment on the teaching learning process.

Hence, the findings of this study confirmed the salient contributions on the use of quality formative assessment for student self-regulation on learning. The use of quality formative assessment helps students to selfregulate their learning and assessment activities. Therefore, department heads, course team leaders, quality assurance officers, educators and students at universities should collaborate and work towards the promotion and use of quality formative assessment on lessons of university courses because quality formative assessment can have salient contributions to improve the student self-regulation on learning and the students' learning and assessment skills. Moreover, continuous professional development trainings which will be organized for university educators shall focus in supporting teachers develop the skills on how to design and implement instructions by integrating quality formative assessment. Furthermore, university educators use quality formative assessment on lessons and prepare the students with self-regulated learning skills so that the students' active involvement in learning and assessing can be improved.

\section{Bibliography}

Andrade, Heidi. "Students as the definitive source of formative assessment: Academic self-assessment and the self-regulation of learning." In NERA Conference Proceedings 2010. Paper 25, edited by Northeastern Educational Research Association (NERA) (Rocky Hill: University of Connectut, 2010. Accessed January, 2013. http://digitalcommons.uconn.edu/nera_2010/25/. 
Bevitt, Sheena. "Assessment innovation student experience: A new assessment challenge and call for a multi-perspective approach to assessment research." Assessment and Evaluation in Higher Education 40, no. 1 (2015):103-119.

Birjandi Parvis and Tamjid Nasrin. "The role of self-assessment in promoting Iranian EFL students' motivation." English Language Teaching 3, no. 3 (2010): 211-220.

Clark, Ian. "Formative assessment: Policy, perspectives and practice." Florida Journal of Educational Administration and Policy 4, no. 2 (2011):158-180.

Cohen, Jacob. Statistical power analysis for the behavioural sciences. New York: Routledge Academic, 1988.

Creswell, John W., Vicki L. Plano Clark, Michelle L. Gutmann, and William E. Hanson. “Advanced Mixed Methods Research Designs.” In Handbook of mixed methods in social and behavioral research, edited by Abbas Tashakkori and Charles Teddlie, 209-239. Thousand Oaks, CA: Sage, 2003.

Creswell, John. Research design: A qualitative, quantitative and mixed-method approaches. $3^{\text {rd }}$ ed. London: Sage Publication inc, 2009.

Hattie, J., and Helen Timperley. "The power of feedback." Review of Educational Research 77, no. 1 (2007): 81-112.

Johansson, Charity H., and Peter Felton. Transforming Students: Fulfilling the Promise of Higher Education. John Hopkins Press, 2014.

Leech, Nancy, and Anthony Onwuegbuzie. "An array of qualitative data analysis tools: A call for data analysis triangulation." School Psychology Quarterly 22, no. 4 (2007): 557-584.

Lu Jing Y and Law Nancy, "Online peer assessments: effects of cognitive and affective feedback." Instructional Science 40, no. 2 (2012):257-275.

Lui, Ngar, and David Careless. "Peer feedback: The learning element of peer assessment." Teaching in Higher Education 11, no. 3 (2006): 279-290.

Nicol, David J, and Debra M. Dick. "Formative assessment and self-regulated learning: a model and seven principles of good feedback practice." Studies in Higher Education 31, no. 2 (2006):199-218.

Pintrich and De Groot, "Motivational and self-regulated learning components of classroom academic performance." Journal of Educational Psychology 82, no. 1 (1990):33-40.

Pintrich, Paul. "The role of goal orientation in self-regulated learning." In Handbook of self-regulation, 452-502, edited by Boekaerts M. Pintrich PR and M. Zeidner. San Diego: CA Academic, 2000.

Punch, Keith. Introduction to social research: Quantitative and qualitative approaches. $2^{\text {nd }}$ ed. New Delhi: Sage, 2005.

Sambell, Kay, and McDowell Liz. "The construction of the hidden curriculum: messages and meaning in the assessment of student learning." Assessment and Evaluation in Higher Education 23, no. 4 (1998):391-402.

Shepard, Lorrie. "Formative assessment: Caveat emptor. The Future of Assessment: Shaping Teaching and Learning." Paper presented at ETS Invitational conference, New York, October 10-11, 2005. 
Wilson, Keithia, and Lizzo Alf. "A just in time intervention to support the academic efficacy of at risk first year students." FYE Pacific Rim Conference: Griffith University, 2008.

Zimmerman, Barry. "Developing Self-Fulfilling Cycles of Academic Regulation: An Analysis of Exemplary Instructional Models." In Self-regulated learning: From teaching to self-reflective practice, edited by DH Schunk and BJ Zimmerman, 1-19. New York: Guilford, 1998.

—. "From Cognitive Modelling to Self-Regulation: A Social Cognitive Career Path.” Educational Psychologist 48, no. 3 (2013): 135-147.

- "Becoming a self-regulated student: An overview." Theory into Practice 41, no. 2 (2002): 64-70.

\section{Annex \\ Title: Self-regulated learning perception measure}

Instruction: For each of the following items, focus on the use of quality formative assessment that promoted your self-regulated learning and assessment. Make a circle to indicate your choice. The meaning of the numbers/choices is shown in the table below.

\begin{tabular}{|lll|}
\hline Keys: & 1 = always not true, & $2=$ mostly not true, \\
& $3=$ mostly true, & $4=$ always true \\
\hline
\end{tabular}

\begin{tabular}{|c|c|c|c|c|c|}
\hline No. & In the general psychology course... & 1 & 2 & 3 & 4 \\
\hline 1 & $\begin{array}{l}\text { Your self-regulated learning was enhanced by formative } \\
\text { assessment }\end{array}$ & 1 & 2 & 3 & 4 \\
\hline 2 & Lesson objectives were communicated to you & 1 & 2 & 3 & 4 \\
\hline 3 & $\begin{array}{l}\text { You were engaged in assessing the progress of your } \\
\text { learning }\end{array}$ & 1 & 2 & 3 & 4 \\
\hline 4 & You had greater control over your own learning & 1 & 2 & 3 & 4 \\
\hline 5 & You managed your learning outcomes actively & 1 & 2 & 3 & 4 \\
\hline 6 & You had a chance to set learning goals & 1 & 2 & 3 & 4 \\
\hline 7 & $\begin{array}{l}\text { You had an opportunity to focus your actions on the } \\
\text { learning goals }\end{array}$ & 1 & 2 & 3 & 4 \\
\hline 8 & $\begin{array}{l}\text { Your confidence has increased because of your control } \\
\text { over the learning }\end{array}$ & 1 & 2 & 3 & 4 \\
\hline
\end{tabular}




\begin{tabular}{|c|l|c|c|c|c|}
\hline No. & \multicolumn{1}{|c|}{ In the general psychology course... } & 1 & 2 & 3 & 4 \\
\hline 9 & You received feedback that improved your learning & 1 & 2 & 3 & 4 \\
\hline 10 & $\begin{array}{l}\text { Your motivation to learn was increased because you had } \\
\text { greater control over your own learning }\end{array}$ & 1 & 2 & 3 & 4 \\
\hline 11 & $\begin{array}{l}\text { Because of the formative assessment used, you } \\
\text { understood your strengths and weaknesses }\end{array}$ & 1 & 2 & 3 & 4 \\
\hline 12 & $\begin{array}{l}\text { You gave yourself feedback to reflect on the correctness } \\
\text { of your actions }\end{array}$ & 1 & 2 & 3 & 4 \\
\hline 13 & $\begin{array}{l}\text { You interpreted the feedback actively given to you by the } \\
\text { educator and your peers }\end{array}$ & 1 & 2 & 3 & 4 \\
\hline
\end{tabular}




\section{The impact of formative assessment on self-regulating learning in university classrooms*}

Fisseha Mikre Weldmeskel and Dreyer Johann Michael $^{* *}$

\section{Copyright}

Copyright for this article is retained by the Publisher. It is an Open Access material that is free for download, distribution, and or reuse in any medium only for non-commercial purposes; provided any applicable legislation is respected, the original work is properly cited, and any changes to the original are clearly indicated. 